City University of New York (CUNY) CUNY Academic Works

\title{
A Pedagogical Search for Home and Care
}

Marta Effinger-Crichlow

CUNY New York City College of Technology

\section{How does access to this work benefit you? Let us know!}

More information about this work at: https://academicworks.cuny.edu/ny_pubs/453

Discover additional works at: https://academicworks.cuny.edu

This work is made publicly available by the City University of New York (CUNY).

Contact: AcademicWorks@cuny.edu 
PART $\mathrm{P}$ II Chapter 40

\title{
A Pedagogical Search for Home and Care
}

\author{
MARTA EFFINGER-CRICHLOW
}

\begin{abstract}
teach at a college, New York City College of Technology, which sits at the foot of a colossal steel-and-granite structure called the Brooklyn Bridge, which opened 鮚 in 1883. A less visible but no less colossal site, the African Burial Ground, also located in Lower Manhattan, serves as the first setting of inquiry for one of the courses I teach in my capacity as a professor of African American Studies. This national monument, this sacred ground, holds the remains of 419 Africans and their descendants. My students learn that it was the only burial site for approximately 15,000 African Americans and their African ancestors during the $1600 \mathrm{~s}$ and $1700 \mathrm{~s}$. It was on the outskirts of town because people of African descent could not be buried with the rest of the population, and African funerals were illegal. When I teach about the burial ground, I emphasize that its location on the outskirts reflects the literal and figurative marginalization of people of African descent. This so-called final resting place signifies, moreover, that people of African descent were not welcome in the city and that their care, even in death, was not of paramount concern to New York's other inhabitants. Despite these oppressive structures, I stress to my students that these burials also illustrate to us today how African people cared for their own, maintained their system of beliefs, resisted being marginalized, and simultaneously articulated their desire for a place-a home:

Broadly interpreted, home is an intimate setting where we first encounter belonging and care. For instance, according to The African Burial Ground: Unearthing the African Presence in Colonial New York, artifacts placed atop the coffins, such as "shells may have symbolized the passage between the realm of the living and the dead, which many African groups associated with water" (U.S. General Services Administration, 100). We might also interpret the shells atop the coffins as a pronouncement about belonging and care. The act of remembering helps this collective to remain rooted in the diaspora. "During the time the African Burial Ground was in use, enslaved Africans probably held one or more ceremonies at graves months or years 434 ] after burial, just as they had done in Africa" (29). The living consistently proclaim
\end{abstract}


that the dead matter. Caring is ritualized and is central to the (re)creation of home, particularly for Africans stripped from their original homes. The African Burial Ground thus becomes a critical site for not only teaching but also knowing, because it helps the students in my Black New York class dissect the visible from the invisible: not only at the site of the burial ground but also in the conceptual space of city, past and present (Richards).

One student reflected, "This picture [of the bones] is so disturbing. When I saw it chills ran down my spine. This picture also makes me think [where are the unidentified bones] of the rest of black New York?" The student identified an absence that was filled with meaning. Without ever using the term "care", my students questioned the ways, both visible and invisible, in which their city treated African peoples in life and in death. My students reside in this same metropolis today and bring their current understandings of New York City into face-to-face and online discussions about their own feelings of belonging. In Reimagining Equality: Stories of Gender, Race, and Finding Home, law professor and scholar Anita Hill says home is "the greatest signifier of our belonging and independence" (40). Hill's text has inspired me to ask myself how might I use additional geographic or symbolic homes, including both. physical sites and digitized spaces, to engage students in critiques about humanity and inhumanity, particularly as they relate to issues of belonging and care (EffingerCrichlow). For instance, what does it mean to be invisible to others and to be denied a home, or to be denied care, in a physical versus a digital space? What does it mean to be visible in a home, of any form, and to use that home to control one's care, to (re)shape the discourse, to memorialize the culture or one's own narrative?

As I have seen in my classes, the African Burial Ground inspires students to act as caregivers of their own New York City neighborhoods and to reject others' stereotypes about their communities. For instance, when a student dared to call the Bronx a borough of decay, another student, reared in the Bronx, offered a verbal tour by describing the ornate architecture of the apartment buildings that line Grand Concourse, a main street. This student sought to protect and validate his home and, in so doing, exhibited an act of care.

Sites like the African Burial Ground fuel my desire to help students understand belonging and care. The earliest Africans in New York and their African American descendants resisted New York's attempt to leave them homeless and erase their existence. Instead, these people of African descent turned inward to reflect on, celebrate, and nurture their collective humanity. Centuries later, these daily acts of care serve as a guide for students as they study and navigate New York's complex landscape.

\section{BIBLIOGRAPHY}

Effinger-Crichlow, Marta. "Mapping Black New York: An Interdisciplinary Search for Home." Keynote address at the National Endowment for the Humanities' (NEH) 
Advanced Topics in the Digital Humanities Summer Institute, Center for Meeting and Learning, Lane Community College, Eugene, Ore., July 15, 2015.

Hill, Anita. Reimagining Equality: Stories of Gender, Race and Finding Home. Boston: Beacon Press, 2011.

Richards, Sandra L. "Writing the Absent Potential: Drama, Performance and the Canon of African-American Literature." In Performance and Performativity, edited by Andrew Parker and Even Kosofsky Sedgwick, 64-88. New York: Routledge, 1995.

U.S. General Services Administration. The New York African Burial Ground: Unearthing the African Presence in Colonial New York. Washington, D.C.: Howard University Press, 2009. 